\title{
Adaptogens stimulate neuropeptide Y and Hsp72 expression and release in neuroglia cells
}

\author{
Alexander Panossian ${ }^{1}$ *, Georg Wikman ${ }^{1}$, Punit Kaur $^{2}$ and Alexzander Asea ${ }^{2}$ * \\ Department of Research and Development, Swedish Herbal Institute Research and Development, Åskloster, Sweden \\ ${ }^{2}$ Division of Investigative Pathology, Scott \& White Memorial Hospital and Clinic, The Texas A\&M Health Science Center College of Medicine, Temple, TX, USA
}

\author{
Edited by: \\ Maria M. Malagon, University of \\ Cordoba, Spain \\ Reviewed by: \\ James A. Carr, Texas Tech University, \\ USA \\ Charlier Dominique Thierry, University \\ of Liege, Belgium \\ *Correspondence: \\ Alexander Panossian, Department of \\ Research and Development, Swedish \\ Herbal Institute Research and \\ Development, Spårvägen 2, SE-432 \\ 96 Åskloster, Sweden. \\ e-mail: alexander.panossian@shi.se; \\ Alexzander Asea, Division of \\ Investigative Pathology, Scott \& White \\ Memorial Hospital and Clinic, The \\ Texas A\&M Health Science Center \\ College of Medicine, 1901 South 1st \\ Street, Temple, TX 76504, USA. \\ e-mail: asea@medicine.tamhsc.edu
}

The beneficial stress-protective effect of adaptogens is related to the regulation of homeostasis via mechanisms of action associated with the hypothalamic-pituitary-adrenal axis and the regulation of key mediators of the stress response, such as molecular chaperones, stress-activated c-Jun $\mathrm{N}$-terminal protein kinase, forkhead box $\mathrm{O}$ transcription factor, cortisol, and nitric oxide (NO). However, it still remains unclear what the primary upstream targets are in response to stimulation by adaptogens. The present study addresses this gap in our knowledge and suggests that an important target for adaptogen mediated stress-protective effector functions is the stress hormone neuropeptide $Y$ (NPY). We demonstrated that ADAPT-232, a fixed combination of adaptogens Eleutherococcus senticosus root extract, Schisandra chinensis berry extract, Rhodiola rosea root extract SHR-5, and its active constituent salidroside, stimulated the expression of NPY and $72 \mathrm{kDa}$ heat shock protein (Hsp72) in isolated human neuroglia cells. The central role of NPY was validated in experiments in which pre-treatment of human neuroglia cells with NPY-siRNA and HSF1-siRNA resulted in the significant suppression of ADAPT-232-induced NPY and Hsp72 release. Taken together our studies suggest that the stimulation and release of the stress hormones, NPY and Hsp72, into systemic circulation is an innate defense response against mild stressors (ADAPT-232), which increase tolerance and adaptation to stress.

Keywords: ADAPT-232, adaptogen, Eleutherococcus senticosus, heat shock proteins, neuropeptide $Y$, salidroside, Schisandra chinensis, Rhodiola rosea

\section{INTRODUCTION}

Adaptogens were initially defined as substances that enhance the "state of non-specific resistance" in stress (Brekhman and Dardymov, 1969; Panossian, 2003), a physiological condition that is linked with various disorders of the neuroendocrine-immune system (Stratakis and Chrousos, 1995). This definition has been updated as "a new class of metabolic regulators which increase the ability of an organism to adapt to environmental factors and to avoid damage from such factors" (Panossian et al., 1999). The term adaptogen was used as a functional claim for certain botanicals and herbal medicinal products in Europe and the USA and the adaptogen concept is now a generally accepted concept (Samuelsson and Bohlin, 2009). A number of clinical trials clearly demonstrated that adaptogens exert an anti-fatigue effect that increases mental work capacity against a background of stress and fatigue, particularly in tolerance to mental exhaustion and enhanced attention (Panossian and Wikman, 2010). Studies on animals and isolated cells have revealed that adaptogens exhibit neuroprotective, antifatigue, antidepressive, anxiolytic, nootropic, and CNS stimulating and tonic effects (Panossian and Wagner, 2005; Panossian and Wikman, 2010). In contrast to conventional stimulants such as

Abbreviations: APC, antigen presenting cells; CFS, chronic fatigue syndrome; JNK1, c-Jun N-terminal protein kinase; FoxO, forkhead box O; HPA, hypothalamicpituitary-adrenal; NO, nitric oxide; NPY, neuropeptide Y; siRNA, short interfering RNA. sympathomimetics (e.g., ephedrine, fenfluramine, phentermine, prolintane) and general tonics, adaptogens do not possess addiction, tolerance and abuse potentials, or impair mental function, or lead to psychotic symptoms with long term use (Panossian and Wikman, 2010). Recent pharmacological studies of a number of adaptogens have provided a rationale for these effects also at the molecular level (Panossian and Wikman, 2010). The stressprotective activity of adaptogens is associated with regulation of homeostasis via several mechanisms of action which are linked to the hypothalamic-pituitary-adrenal (HPA) axis and the regulation of key mediators of the stress response, including cortisol, nitric oxide, stress-activated protein kinase c-Jun $\mathrm{N}$-terminal protein kinase (JNK; Panossian et al., 2007), forkhead box O (FoxO) transcription factor (DAF-16; Wiegant et al., 2009), and molecular chaperones (Chiu and Ko, 2004; Panossian and Wikman, 2010). However, it still remains unclear what the primary upstream targets are in response to stimulation by adaptogens. In this study, we investigate whether heat shock factor 1 (HSF1) and Neuropeptide Y (NPY) might be one of the primary upstream targets of adaptogens in neuroglia cells.

Neuropeptide $\mathrm{Y}$ is a stress-responsive hormone widely distributed in the central and peripheral nervous system (Tatemoto et al., 1982; Irwin, 2008). In the brain the concentrations of NPY are significantly higher than other neuropeptides, and is found mainly in the limbic system, including the amygdala and the hypothalamus, which are areas of the brain involved in the regulation of 
emotional behaviors and stress response (Dumont et al., 1993; Smialowska et al., 2007). In the peripheral nervous system, NPY is concentrated in sympathetic nerve endings (Irwin, 2008). Sympathoadrenal activation during the stress response results in NPY release from the sympathetic nerve endings either alone or with catecholamines (Morris et al., 1986). NPY release follows stressors including strenuous exercise (Karamouzis et al., 2002), panic disorders (Boulenger et al., 1996), cold exposure (Kellogg, 2006), and chronic fatigue syndrome (CFS; Fletcher et al., 2010). The elevation of NPY in blood of CFS patients is associated with severity of stress, negative mood, and clinical symptoms (Fletcher et al., 2010). On the other hand, psychological stress elevated plasma NPY in healthy subjects (Morgan et al., 2001). In the periphery, sympathetic nerve- and platelet-derived NPY act in a stimulatory fashion; synergizing with glucocorticoids and catecholamines to potentiate the stress response, induce vasoconstriction and increase vascular smooth muscle cell proliferation. However, in the brain NPY acts as an anxiolytic and inhibits sympathetic activity which results in lowering blood pressure and heart rate (Morris et al., 1986; Kuo et al., 2007), and inhibiting the production of cortisol in human adrenal cells (Kempna et al., 2010). NPY can regulate both immune cells and neuronal cells, e.g., NPY strongly inhibits NO synthesis through $\mathrm{Y}(1)$ receptor activation, which prevents IL- $1 \beta$ release and thus inhibits nuclear translocation of NF- $\kappa \mathrm{B}$ in microglia (Ferreira et al., 2010). NPY plays a protective role in viral infections associated with glial cell activation and the production of proinflammatory cytokines in the CNS (Du et al., 2010). It has been suggested that the stimulation of NPY gene expression is related to food deprivation and its overexpression causes disordered energy balance leading to increased eating (Yang et al., 2009). Within cells, NPY decreases the expression of mitochondrial uncoupling protein, thereby promoting ATP formation (Billington et al., 1994). NPY stimulates the corticotrophic axis (Small et al., 1997), modulates the secretion of various hypothalamic neuropeptides and cognition (Redrobe et al., 1999). Administration of NPY reduced cortisol secretion during night hours in healthy subjects (Antonijevic et al., 2000). In addition, NPY is known to play a role in the pathophysiology of depression (Heilig et al., 1988). It has been shown that NPY displayed antidepressant-like activity in the rat forced swimming test (Stogner and Holmes, 2000; Redrobe et al., 2002). Human studies have revealed a role for NPY in adaptation to stress ("buffering" the harmful effects of stress; Morgan et al., 2000, 2001; Morales-Medina et al., 2010). There is a plethora of pre-clinical and clinical evidence suggesting a mood and cognitive performance improving action for NPY (Morgan et al., 2000; Fletcher et al., 2010). Higher levels of NPY have been observed in soldiers who either present with reduced psychological distress or belong to the elite Special Forces branch (Morgan et al., 2000, 2001). In contrast, decreased levels of NPY were observed in depression and in brain tissues of suicide victims (Morales-Medina et al., 2010).

The $72 \mathrm{kDa}$ heat shock protein (Hsp72) plays an important role in pharmacological effects of adaptogens (Panossian et al., 2010). Hsp72 functions both as a chaperone by binding important antigenic peptides for delivery to antigen presenting cells (APC), and as a cytokine by stimulating pro-inflammatory cytokine release. This dual function of Hsp72 is termed the chaperokine activity (Asea,
2003, 2006, 2007, 2008; Hecker and McGarvey, 2011). Recently, we demonstrated the stimulating effect of ADAPT-232, a fixed combination of extracts of three most efficient adaptogens (Rhodiola rosea, Eleutherococcus senticosus, and Schisandra chinensis), is associated with significant increase of circulated Hsp72 in rats (Panossian et al., 2009). However, the target cells for ADAPT-232induced effects or the cells releasing Hsp72 have not yet been identified.

\section{MATERIALS AND METHODS TEST ARTICLE}

ADAPT-232 forte is a proprietary name of a fixed combination of three genuine (native) extracts of E. senticosus (Rupr. et Maxim) Harms root, S. chinensis (Turcz.) Baill. root, $R$. rosea L., root, characterized for the content of eleutherosides $\mathrm{E}$ and B $(0.17 \%)$, schisandrin and $\gamma$-schisandrin $(0.85 \%)$, salidroside $(0.33 \%)$, tyrosol $(0.07 \%)$, rosavin $(0.37 \%)$, triandrin $(0.01 \%$; Panossian et al., 2009). The amounts of the active markers salidroside, rosavin, tyrosol, triandrin, eleutheroside $\mathrm{B}$, eleutheroside $\mathrm{E}$, schizandrin, and $\gamma$-schizandrin were determined by analytical RP-HPLC using an acetonitrile-water gradient system as mobile phase. Peaks were detected by UV-PAD and analytes quantified at $221 \mathrm{~nm}$ (rhodioloside and tyrosol), $252 \mathrm{~nm}$ (rosavin), $262 \mathrm{~nm}$ (triandrin), $220 \mathrm{~nm}$ (eleutheroside B), $210 \mathrm{~nm}$ (eleutheroside $\mathrm{E}$, schizandrin, and $\gamma$-schizandrin). Analytical methods were validated for selectivity, peak purity, precision (RSD $<5 \%$ ), and accuracy in the range $50-150 \%$ of the target amounts of analytes in the tablets in accordance with ICH guidelines using Effi Validation 3 software (version 1.03) for testing and calibration laboratories subject to EN ISO/IEC 17 025:2001. Samples used in experiments were prepared by dilution of stock solutions of ADAPT-232 $(10 \mathrm{mg} / \mathrm{ml})$ or salidroside $\left(3 \mathrm{mg} / \mathrm{ml}, 10^{-2} \mathrm{M}\right)$ with PBS. Fifty microliters of working solutions were added to $10 \mathrm{ml}$ of cell culture in order to obtain final concentrations of $0.5,1,5$, and $10 \mu \mathrm{M}$ salidroside and $0.005,0.05,0.5$, and $5 \mu \mathrm{g} / \mathrm{ml}$ of ADAPT-232 (containing 0.05, 0.5, 5 , and $50 \mathrm{nM}$ salidroside) in culture media.

\section{REAGENTS}

Control peptide, PB1 is a synthetic peptide containing an $\mathrm{N}$-terminal cysteine (CTRSRHSSYPNEYEEDEEMEEEL); the sequence is derived from mouse Bad (New England Biolabs, Ipswich, MA, USA). The NPY peptide (Sequence H-Tyr-Pro-SerLys-Pro-Asp-Asn-Pro-Gly-Glu-Asp-Ala-Pro-Ala-Glu-Asp-MetAla-Arg-Tyr-Tyr-Ser-Ala-Leu-Arg-His-Tyr-Ile-Asn-Leu-Ile-ThrArg-Gln-Arg-Tyr- $\mathrm{NH}_{2}$ acetate salt) was purchased from Bachem (Torrance, CA, USA). NPY-siRNA and HSF1-siRNA were purchased from Santa Cruz Biotechnology (Santa Cruz, CA, USA). Hsp72-siRNA and control-siRNA were purchased from Dharmacon RNA Technologies (Lafayette, CO, USA).

\section{CELL LINES AND CULTURE CONDITIONS}

The human neuroglia cell line T98G (ATCC, CRL-1690) has a hyperpentaploid chromosome count that was derived from a 61year-old Caucasian male with glioblastoma multiforme. Human neuroglia T98G cells were cultured from ATCC-formulated Eagle's Minimum Essential Medium (Catalog No. 30-2003) with fetal bovine serum to a final concentration of $10 \%, 100 \mathrm{U} / \mathrm{ml}$ penicillin, $100 \mu \mathrm{g} / \mathrm{ml}$ streptomycin (ICN, Aurora, OH, USA). To avoid 
stress induced by cell overgrowth, cultures were maintained in a $37^{\circ} \mathrm{C}$ incubator in humidified air with $5 \% \mathrm{CO}_{2}$ atmosphere. Cells were maintained at a density of $2 \times 10^{5}$ cells $/ \mathrm{ml}$ and passaged with fresh complete medium every 3-4 days. Cell viability was assessed using trypan blue exclusion test and routinely found to contain $<5 \%$ dead cells.

\section{PROTEIN SEPARATION AND WESTERN BLOT ANALYSIS}

Following various treatment protocols cells were washed once with complete medium, centrifuged, and pellets lysed with $100 \mu \mathrm{l}$ of lysing buffer containing a cocktail of protease inhibitors (antipain, bestain, chymostatin, E-64, pepstatin, phosphoramidon, pefabloc, EDTA, aprotinin; Complete Protease Inhibitor Cocktail Tablets ${ }^{\circledR}$, Roche Diagnostics). Cells were then incubated for $30 \mathrm{~min}$ on ice and sonicated (Brandson 1510) for $15 \mathrm{~min}$. The cell suspension was passed through a 26-gage needle and protein quantification was performed using the Bradford method. Proteins were separated in a precast $10 \%$ SDS-PAGE Novex ${ }^{\circledR}$ Tricine gel (Invitrogen) by carefully placing $3 \mu \mathrm{g}$ of protein in each lane. Nitrocellulose membrane (GIBCO BRL) was used to transfer the proteins and the membrane blocked with 5\% skim milk (in TBS 1\% pH 7.4 and $0.01 \%$ Tween-20) and incubated for $1 \mathrm{~h}$ at room temperature with appropriate primary antibody; anti-Hsp72 (Stressgen Biotechnologies, BC, Canada), anti-NPY (Assay Design, BC, Canada), or anti- $\beta$-actin (Oncogene, San Diego, CA, USA). Blots were incubated $50 \mathrm{~min}$ at room temperature with $0.5 \mu \mathrm{g}$ of appropriate species matched anti-peroxidase and the reaction was detected using the Luminol reagent for chemiluminescence (Santa Cruz Biotechnology). The intensity of the bands were analyzed by densitometry with a video densitometer (Chemilmager ${ }^{\mathrm{TM}}$ 5500; Alpha Innotech, San Leandro, CA, USA) using the AAB software (American Applied Biology).

\section{MEASUREMENT OF LACTATE DEHYDROGENASE RELEASE}

Lactate dehydrogenase (LDH) is a stable cytosolic enzyme that is released upon cell lysis. LDH released into cell culture media by dead cells and total LDH contained in living cells was measured using the CytoTox 96 Non-Radioactive Cytotoxicity Assay according to the manufacturer's instructions (Promega, Madison, WI, USA). Briefly, after various treatment protocols, culture medium $(500 \mu \mathrm{l})$ was removed and the remaining cells lysed by adding $500 \mu \mathrm{l}$ of $5 \%$ Triton X-100 solution. After $30 \mathrm{~min}$ at room temperature, cell lysate was recovered and incubated for an additional 30 min in the dark with a buffer containing $\mathrm{NAD}^{+}$, lactate, and tetrazolium. $\mathrm{LDH}$ converts lactate to pyruvate, generating $\mathrm{NADH}$ which reduces tetrazolium (yellow) to formazan (red), which is detected by fluorescence $(490 \mathrm{~nm})$. LDH release, a marker for cell death was expressed as a percentage of the $\mathrm{LDH}$ in the medium over the total LDH (lysate).

\section{ENZYME LINKED IMMUNOSSORBANT ASSAY}

After treatment the human neuroglia cell line T98G was centrifuged to discard floating cells and cellular debris and the total protein content was determined by Bradford analysis using bovine serum albumin as a standard. The supernatant was aliquoted and treated with or without $1 \%$ Triton X-100 or $1 \%$ Lubrol WX or $0.5 \%$ Brij 98 for $10 \mathrm{~min}$ at $4^{\circ} \mathrm{C}$ with gentle rocking and
Hsp72 content measured by standard sandwich Enzyme linked immunossorbant assay (ELISA). Briefly, 96-well microtiter plates (Nunc Immunoplate Maxisorp; Life Technologies) were coated with murine monoclonal anti-human Hsp72 (clone C92F3A-5; Stressgen) in carbonate buffer, pH $9.5(2 \mu \mathrm{g} / \mathrm{mL})$ overnight at $4^{\circ} \mathrm{C}$. Plates were then washed with PBS containing 1\% Tween-20 (PBS$\mathrm{T})$ and blocked by incubation with $1 \%$ bovine serum albumin in PBS-T. Supernatant was added and bound Hsp72 was detected by the addition of rabbit polyclonal anti-Hsp72 antibody (SPA812; Stressgen). Bound polyclonal antibody was detected with alkaline phosphatase-conjugated murine monoclonal antibody to rabbit immunoglobulins (Sigma Chemical Co), followed by $p$ nitrophenyl phosphate substrate (Sigma Chemical Co). The resultant absorbance was measured at $405 \mathrm{~nm}$ with a Bio-Rad Benmark Plus plate reader. Standard dose-response curves were generated in parallel with Hsp72 (0-20,000 ng/mL; Stressgen), and the concentrations of Hsp72 were determined by reference to these standard curves with ASSAYZAP data analysis software (BIOSOFT). The interassay variability of the Hsp72 immunoassays was $<10 \%$.

\section{NPY ENZYME IMMUNOASSAY}

Human neuroglia cells were grown to $75 \%$ confluence. Twentyfour hours prior to measuring NPY release, cell culture medium was replaced with serum-free DMEM, then incubated with ADAPT-232, or salidroside, or exposed to heat shock $\left(41^{\circ} \mathrm{C}\right.$, $60 \mathrm{~min}$ ) and incubated for $24 \mathrm{~h}$ in a $37^{\circ} \mathrm{C}$ incubator. Supernatant was recovered in quadruplicates, centrifuged to clear cellular debris and NPY concentration was measured using the NPY enzyme immunoassay kit (assay sensitivity of $0.09 \mathrm{ng} / \mathrm{ml}$ ) according to the manufacturer's instructions (Phoenix Pharmaceuticals, CA, USA). Briefly, cleared supernatant was added to 96-well plates containing primary antibody and biotinylated peptide and incubated at room temperature for $2 \mathrm{~h}$. Plates were washed and SA-HRP solution was added to the well and incubated for a further $1 \mathrm{~h}$ at room temperature. After washing the plates TMB substrate was added and incubated for an additional $1 \mathrm{~h}$ at room temperature. The test was terminated by adding $2 \mathrm{~N} \mathrm{HCl}$ to the wells. The resultant absorbance was measured at $450 \mathrm{~nm}$ with a Bio-Rad Benmark Plus plate reader. The concentration of NPY was determined by reference to these standard curves with ASSAYZAP data analysis software (BIOSOFT). The interassay variability of the NPY enzyme immunoassays was $<10 \%$.

\section{SIRNA-MEDIATED GENE SILENCING ASSAYS}

The hsp72 gene silencing was achieved by using a vector-based system to produce hairpin RNA. The criteria that were used to silence the hsp72 gene have previously been established. To design the siRNA duplexes a search for 23-nucleotide motif with AA (N19) TT was performed in which the target sites were selected from a gene sequence beginning at 50-100 nucleotides downstream of the start codon. Hits with $\sim 50 \% \mathrm{G} / \mathrm{C}$-content were selected and antisense RNA was synthesized as the complement to position 1-21 of the 23-nucleotide motif. Finally, symmetric 3 '-overhangs that help to ensure that siRNA are formed with approximately equal ratios of sense and anti-sense target RNA-cleaving siRNA. The 21-base pair product, Hsp72-siRNA was cloned into the pSuper vector under the restriction of BglII and HindIII. This construct was 
then co-transfected with a green fluorescent protein (GFP) plasmid into the THP1 human monocytic cells. Splicing of the hairpin resulted in 21-mer long dsRNA. Psuper vector (Oligoengine, Seattle, WA, USA) was used to introduce a 64-base oligomer to form the hairpin with Hsp72 specific sequence. A chemically synthesized 21-mer-nucleotide DNA to silence the $h s p 72$ gene was used and cloned into the pSuper vector-based silencing (Oligoengine). The primers were designed using web-based proprietary software from Oligoengine and three 21-mer gene sequences were selected that predicted it would successfully silence the $h s p 72$ gene. The sequence used in this study was Hsp72 sequence $5^{\prime}$ AGCCCGAGCTGGGAACCATT-3' (GenBank Accession Number LO7577). This 21-base was synthesized with defined sequences to provide two restriction sites (BglII and HindIII) and on transcription form a hairpin, in order to initiate gene silencing. The total length of the primer was 64-mer including the specific sequences of Hsp72. A complementary oligonucleotide was also synthesized from Oligoengine (Seattle, WA, USA). The primers were incubated in annealing buffer ( $100 \mathrm{mM}$ potassium acetate, $30 \mathrm{mM}$ HEPES$\mathrm{KOH} \mathrm{pH} 7.4,2 \mathrm{mM}$ magnesium acetate) at $95^{\circ} \mathrm{C}$ for $5 \mathrm{~min}$ and incubated overnight at room temperature. After digesting double stranded oligo and pSuper vector with HindIII and BglII restriction enzymes, primers were annealed and cloned into the pSuper vector. Positive clones were sequenced.

\section{TRANSFECTION AND CELL SORTING}

THP1 cells were transfected with pSuper-Hsp72 and pGFP using the lipid transfection reagent, Effectene, according to the manufacturer's instructions (Qiagen, Valencia, CA, USA). Briefly, $3 \times 10^{5}$ exponentially growing cells were seeded in $60 \mathrm{~mm}$ tissue culture plates and a mixture of $1 \mu \mathrm{g}$ GFP plasmid DNA and $1 \mu \mathrm{g}$ pSuperHsp72 plasmid in Effectene was added to the cells and incubated for $18 \mathrm{~h}$ at $37^{\circ} \mathrm{C}$. After $48 \mathrm{~h}$ cells were harvested and immediately sorted into GFP positive and negative subpopulations using a MoFlow cytometer (Dakocytomation, Carpinteria, CA, USA). Briefly, individual cells were gated on the basis of forward scatter (FSC) and orthogonal scatter (SSC). The photomultiplier (PMT) for GFP (FL1-height) was set on a logarithmic scale. Cell debris was excluded by raising the FSC-height PMT threshold. The flow rate was adjusted to $<200$ cells/s and at least $10^{5}$ cells were sorted for each sample group.

\section{STATISTICAL ANALYSIS}

Data obtained from Western blot was analyzed according to the relationship between the signal intensity and the area and presented as optical density (OD). Data from flow cytometry was shown as histograms and fluorescent arbitrary units and the mean fluorescent intensity was obtained to compare between groups. Data management and statistical analyses were performed using GraphPad (San Diego, CA, USA) and Prism software (version 3.03 for Windows). The significance of the between-group differences (at 95\% confidence intervals) were determined using one-way parametric analysis of variance (ANOVA) with Tukey's multiple comparison post test. The $F$ test statistic was found by dividing the between-group variance by the within group variance (mean squared deviations from the mean, MSB/MSW, obtained by dividing of the Sum of Squares on the degrees of freedom (df) for the between group and within group). Data were shown in absolute $(\mathrm{ng} / \mathrm{ml}, \mu \mathrm{M})$ or normalized (as percentages) values, mean and SD, and $p$ values $<0.05$ were considered statistically significant.

\section{RESULTS}

In this study, we demonstrate that neuroglia cells are one possible target cell that mediates ADAPT-232-induced effects. We further demonstrate that ADAPT-232 stimulates the expression of NPY and Hsp72 release from neuroglia cells in a concentrationdependent fashion. Our present study suggests NPY might be one of the primary upstream targets of adaptogens. Our present study suggests that HSF1 and NPY might be the primary upstream targets of adaptogens.

\section{ADAPT-232 STIMULATES THE EXPRESSION OF NPY AND HSP72 IN HUMAN NEUROGLIA CELLS}

Human neuroglia cells were treated with ADAPT-232 and the expression of Hsp72 and NPY was measured by Western blot analysis. We demonstrated that treatment of human neuroglia cells with ADAPT-232 or salidroside dose-dependently increased NPY expression and the expression the stress protein, Hsp72. Maximum effect of ADAPT-232 required $0.5 \mu \mathrm{g} / \mathrm{ml}$ of the genuine plant extracts containing salidroside in the final concentration of $5.5 \mathrm{nM}(p<0.01)$ (Figure 1). Interestingly, the treatment of human neuroglia cells with salidroside induced a similar doseresponse curves, albeit, requiring 1,000 times higher concentration of salidroside $(5 \mu \mathrm{M})$ to achieve maximum NPY expression $(p<0.01$; Figure 2).

\section{HUMAN NEUROGLIA CELLS RELEASE NPY AND HSP72 IN RESPONSE TO STIMULATION WITH ADAPT-232}

We previously demonstrated that ADAPT-232 strongly augments endurance of mice in a forced swimming experiment (a model that combined physical and emotional stresses), and that there

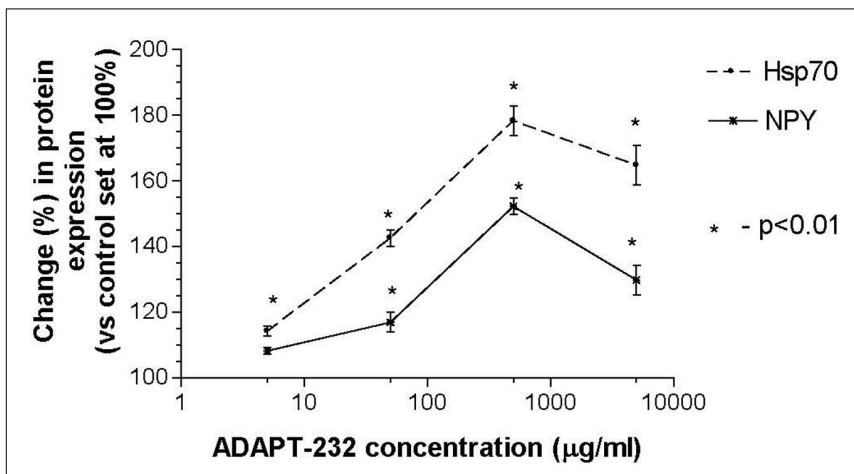

FIGURE 1 | ADAPT-232 dose-dependently increases NPY and Hsp72 expression in human neuroglia cells. ADAPT-232 and salidroside was admixed with $10^{6}$ human neuroglia cells at the indicated concentrations and incubated for $24 \mathrm{~h}$ at $37^{\circ} \mathrm{C}$ in $5 \% \mathrm{CO}_{2}$ atmosphere. Cells were lysed and NPY Hsp72 protein expression was determined using Western blot analysis as described in detail in the Section "Materials and Methods." The intensity of the bands were analyzed by densitometry with a video densitometer (ChemilmagerTM 5500; Alpha Innotech, San Leandro, CA, USA) using the $A A B$ software (American Applied Biology). Data are the percentage (\%) change in protein density expression as compared to control $( \pm S D)$ 


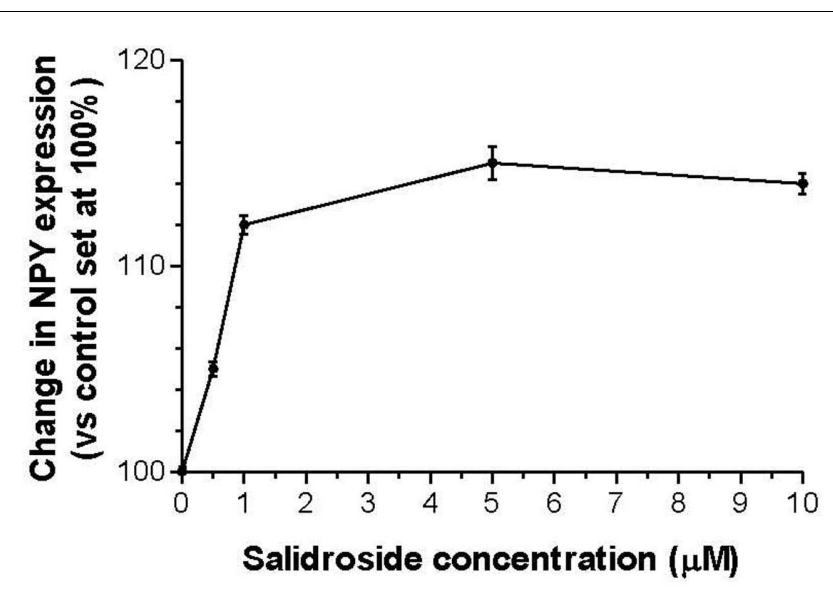

FIGURE 2 | Salidroside dose-dependently increases NPY expression in human neuroglia cells. Salidroside was admixed with $10^{6}$ human neuroglia cells at the indicated concentrations and incubated for $24 \mathrm{~h}$ at $37^{\circ} \mathrm{C}$ in $5 \% \mathrm{CO}_{2}$ atmosphere. Cells were lysed and NPY expression was determined using Western blot analysis as described in detail in the Section "Materials and Methods." The intensity of the bands were analyzed by densitometry with a video densitometer (Chemilmager ${ }^{\mathrm{TM}}$ 5500; Alpha Innotech, San Leandro, CA, USA) using the AAB software (American Applied Biology). Data are the percentage (\%) change in protein density expression as compared to control $( \pm S D)$.

was a concomitant increase in serum Hsp72 levels (Panossian et al., 2009). To test our working hypothesis that human neuroglia cells release Hsp72, cells were treated with ADAPT-232 or salidroside for $24 \mathrm{~h}$ in a $37^{\circ} \mathrm{C}$ incubator and the concentration of NPY and Hsp72 in the supernatant was measured by Hsp72 ELISA. We demonstrated a dose-dependent release of NPY and Hsp72 into the supernatant of cultured human neuroglia cells ( $p<0.0001$; Table 1). To negate the possibility that the adaptogens were inducing Hsp72 release by stimulating necrotic cell death, in the same experiment supernatant was subjected to LDH assay for the determination of cell death. We demonstrated that there was no significant increase in cell death at the concentrations of $0.005-0.5 \mathrm{mg} / \mathrm{L}$ of ADAPT-232, as compared to control $(0 \mathrm{mg} / \mathrm{L}$; PBS only) or exposure of cell to non-lethal heat shock treatment $\left(41^{\circ} \mathrm{C}, 60 \mathrm{~min}\right.$; Table 1$)$.

\section{ADAPT-232-INDUCED RELEASE OF HSP72 AND NPY FROM HUMAN NEUROGLIA CELLS IS DEPENDENT ON THE TRANSCRIPTION FACTOR HSF1}

We next explored the mechanistic basis for the induction of Hsp72, to determine if it was primary or secondary to the ADAPT-232 response. This is important since, if the induction of Hsp72 is a secondary event, upstream events would be of the primary interest. The treatment of human neuroglia cells with ADAPT232 or salidroside significantly increased the expression of HSF1 as judged by Western blot analysis (Figure $\mathbf{3 A}$ ). To prove that the adaptogens stimulate Hsp72 release by a mechanism dependent HSF1, the expression of HSF1 was significantly silenced using siRNA directed against $h s f-1$ gene (HSF1-siRNA) before treatment with the adaptogens, as compared to neuroglia cells pre-treated with control-siRNA (Figure 3A). Control-siRNA is a non-targeting 20-25 nucleotide siRNA designed as a negative control, with sequences that do not target any gene product nor has any significant sequence similarity to mouse, rat, or human gene sequences, and has been tested in cell-based screens and proved to have no significant effect on cell proliferation, viability, or morphology, according to the manufacturer (Dharmacon RNA Technologies, Lafayette, CO, USA). We further demonstrated that pre-treatment of human neuroglia cells with HSF1-siRNA strongly suppressed the expression of Hsp72 (Figure 3B) and release of Hsp72 and NPY (Figure 5) stimulated by ADAPT232 and salidroside, as compared to neuroglia cells pre-treated with control-siRNA (Figures 3B and 5A). The possibility that the release of Hsp72 from human neuroglia cells was due to cell death was negated by results showing that adaptogens increased significant release of Hsp72 as judged by ELISA $(p<0.05)$, but there was no similar increase in cell death, as confirmed by the LDH assay.

\section{NPY PEPTIDE STIMULATES HSP72 RELEASE FROM HUMAN NEUROGLIA CELLS IN AN AUTOCRINE LOOP}

To determine if NPY peptide itself can stimulate Hsp72 expression, human neuroglia cells were treated with NPY peptide and Hsp72 release measured in the supernatant $24 \mathrm{~h}$ post treatment. We demonstrated that treatment of human neuroglia cells with NPY peptide dose-dependently increased the expression (Figure 4A) and significant release of Hsp72 $(p<0.05$; Figure 6). We further demonstrated that silencing the expression of intracellular NPY by pre-treating human neuroglia with NPY-siRNA effectively suppressed the expression of Hsp72 (Figure 4A). The pre-treatment of human neuroglia cells with NPY-siRNA significantly suppressed the expression of ADAPT-232- and salidroside-mediated upregulation of intracellular Hsp72 expression (Figure 4B) and concomitantly resulted in a significant suppression of $\mathrm{Hsp} 72$ release, as compared to neuroglia cells pre-treated with control-siRNA (Figure 6). Cell death was excluded as a possible reason for increased Hsp72 release by experiments in which culture supernatant was probed for signs of cell death using LDH assay. We demonstrated that the significant increase in Hsp72 release in response to NPY was not followed by a similar increase in cell death (Figure 6). To determine the role of NPY in ADAPT-232- and salidroside-mediated responses, we demonstrated that silencing NPY expression in human neuroglia cells by pre-treatment with NPY-siRNA strongly suppressed ADAPT-232- and salidrosideinduced increase in Hsp72 expression, as compared to neuroglia cells pre-treated with control-siRNA (Figure 4C). Taken together, these findings are consistent with a recent study which reports that NPY promotes the expression of intracellular Hsp72 in rat renal vascular smooth muscle (Zhong et al., 2003).

\section{DISCUSSION}

ADAPT-232 is a combination of extracts of three well studied and efficient adaptogenic plants $-R$. rosea, E. senticosus, and $S$. chinensis (Panossian and Wikman, 2008; Panossian et al., 2011). Their effects on CNS have been recently reviewed (Panossian and Wikman, 2010). Clinical efficacy of single and repeated doses of ADAPT-232 on cognitive functions and mental performance of healthy volunteers, cosmonauts (Bogatova et al., 1997; Aslanyan et al., 2010), and patients with pneumonia (Narimanian et al., 
Table 1 | Human neuroglia cells release NPY and Hsp72 in response to treatment with ADAPT-232 and its active constituent salidroside.

\begin{tabular}{|c|c|c|c|c|}
\hline \multicolumn{2}{|c|}{ Treatment (concentration) $^{a}$} & Mean Hsp72 conc. $(\mathrm{ng} / \mathrm{ml} \pm \mathrm{SD})^{\mathrm{b}}$ & Mean NPY conc. $(\mathrm{ng} / \mathrm{ml} \pm \mathrm{SD})^{\mathrm{c}}$ & Mean cell death $(\% \pm \mathrm{SD})^{c}$ \\
\hline 0 & 0 & $35 \pm 9$ & $1.2 \pm 0.2$ & $8 \pm 5$ \\
\hline 0.05 & $(0.0005)^{\dagger}$ & $95 \pm 10^{* *}$ & $5.7 \pm 0.3^{* *}$ & $7 \pm 6$ \\
\hline 0.5 & $(0.005)^{\dagger}$ & $124 \pm 15^{* *}$ & $9.5 \pm 0.5^{* *}$ & $12 \pm 7$ \\
\hline \multirow[t]{3}{*}{5.0} & $(0.05)^{\dagger}$ & $165 \pm 12 * *$ & $9.8 \pm 1.6^{* *}$ & $36 \pm 10^{* *}$ \\
\hline & & $d f=19(4 / 15)$ & $d f=19(4 / 15)$ & $d f=14(4 / 10)$ \\
\hline & & $P<0.0001$ & $P<0.0001$ & $P=0.0017$ \\
\hline \multicolumn{5}{|l|}{ Salidroside $(\mu \mathrm{M})$} \\
\hline 0 & & $40 \pm 9$ & $1.1 \pm 0.3$ & $10 \pm 5$ \\
\hline 0.5 & & $57 \pm 6^{*}$ & $6.8 \pm 0.5^{* *}$ & $9 \pm 3$ \\
\hline \multirow{2}{*}{$\begin{array}{l}5.0 \\
10.0\end{array}$} & & $d f=14(4 / 15)$ & $d f=14(4 / 15)$ & $d f=14(4 / 10)$ \\
\hline & & $P<0.0001$ & $P<0.0001$ & $P=0.0021$ \\
\hline \multicolumn{2}{|c|}{ Heat shock $\left(41^{\circ} \mathrm{C}, 60 \mathrm{~min}\right)$} & $2086 \pm 276^{* *}$ & $31.5 \pm 10^{* *}$ & $23 \pm 15$ \\
\hline
\end{tabular}

${ }^{+}$Concentration of salidroside released from ADAPT-232 in the cell culture.

${ }^{a}$ Human neuroglia cells $\left(10^{6}\right)$ were treated with various concentrations of ADAPT-232 or salidroside or exposed to heat shock $\left(41^{\circ} \mathrm{C}, 60 \mathrm{~min}\right)$ and incubated for $24 \mathrm{~h}$ in a $37^{\circ} \mathrm{C}$ incubator.

${ }^{b}$ Twenty-four hours after treatment protocols the supernatant from human neuroglia cells were recovered, centrifuged to clear cellular debris and Hsp72 concentration was measured using the classical Hsp72 ELISA as described in detail in the Section "Materials and Methods." Data are the mean concentration of Hsp72 (ng/m/ \pm SD) and is the sum of four independent experiments performed in quadruplicates. ${ }^{*} p<0.05 \mathrm{vs}$ control $(0 \mu \mathrm{g} / \mathrm{ml}),{ }^{* *} p<0.001 \mathrm{vs}$ control in Tukey's multiple comparison post test.

${ }^{c}$ Human neuroglia cells were grown to $75 \%$ confluence. Twenty-four hours prior to measuring NPY release, cell culture medium was replaced with serum-free DMEM, then incubated with ADAPT-232, or salidroside, or exposed to heat shock $\left.141^{\circ} \mathrm{C}, 60 \mathrm{~min}\right)$ and incubated for $24 \mathrm{~h}$ in a $37^{\circ} \mathrm{C}$ incubator. Supernatant was recovered in quadruplicates, centrifuged to clear cellular debris and NPY concentration was measured using the NPY enzyme immunoassay kit (assay sensitivity of 0.09 ng/ml) according to the manufacturer's instructions (Phoenix Pharmaceuticals, CA, USA). Data are the mean concentration of NPY (ng/m/ $\pm S D$ ) and is the sum of four independent experiments performed in quadruplicates. ${ }^{*} p<0.05 \mathrm{vs}$ control $(0 \mu \mathrm{g} / \mathrm{ml}$ genuine extracts), $p<0.001 \mathrm{vs} \mathrm{control} \mathrm{in} \mathrm{Tukey's} \mathrm{multiple} \mathrm{comparison} \mathrm{post} \mathrm{test.}$ ${ }^{d}$ Twenty-four hours after treatment protocols the supernatant from human neuroglia cells and viability assayed using the CytoTox 96 Non-Radioactive Cytotoxicity Assay according to the manufactures instructions (Promega), and the percentage of $L D H$ released vs total $L D H$ was calculated. Data are mean percentage cell death \pm SD and represent three independently performed experiments in quadruplicates. ${ }^{*} p<0.01 \mathrm{vs}$ control $(0 \mu \mathrm{g} / \mathrm{m} /$ genuine extracts) in Tukey's multiple comparison post test.

2005) have been studied. Interestingly, the long term treatment of aged rats with ADAPT-232 diminished or prevented a range of age-related disorders including malfunction of the central nervous system, loss of memory, and loss of learning ability (Makarov et al., 2007).

Recently, we demonstrated that ADAPT-232 significantly increased tolerance to stress, augmenting the endurance of mice in a swimming test model. This effect was associated with a dramatic increase in the blood level of circulating Hsp72 (Panossian et al., 2009). However, in that study the target cell was not identified. In the present study, we demonstrated that ADAPT-232 and its active constituent salidroside stimulate the expression (Figures 1, 2, 3B, and $4 \mathrm{~B}, \mathrm{C}$ ) and release (Table 1; Figure 5) of NPY and the stress protein Hsp72 from isolated human brain glioblastoma T98G cells. There is now strong evidence that NPY are synthesized in astrocytes, oligodendrocytes, microglia, and Schwann cells in vivo (Ubink et al., 2003). We speculate that human normal neuroglia cells might be one of the target cells for ADAPT-232 (and its active constituent salidroside) as well. Further studies supporting this hypothesis are currently ongoing in our laboratory (Kaur et al., in preparation).

Neuropeptide $\mathrm{Y}$ is known to perform a wide range of biological functions through the interaction with distinct G-protein-coupled receptors (Wahlestedt and Reis, 1993). Table 2 illustrates the similarities in pharmacological profiles of NPY and adaptogens. Table 3 exemplifies several NPY-mediated beneficial effects and other potential effects of adaptogens in various disorders. Taken together, the data presented in Tables 2 and 3 suggests that a stressprotective activity of adaptogens is mainly associated with effects of Hsp72, while stimulating activity of adaptogens - with NPY.

Neuropeptide $\mathrm{Y}$ is known to play an essential role in the basic mechanisms of morphine tolerance and opioid dependence (Woldbye et al., 1998). Morphine significantly decreases NPY levels in the hypothalamus, the striatum, and the adrenal glands (Pages 


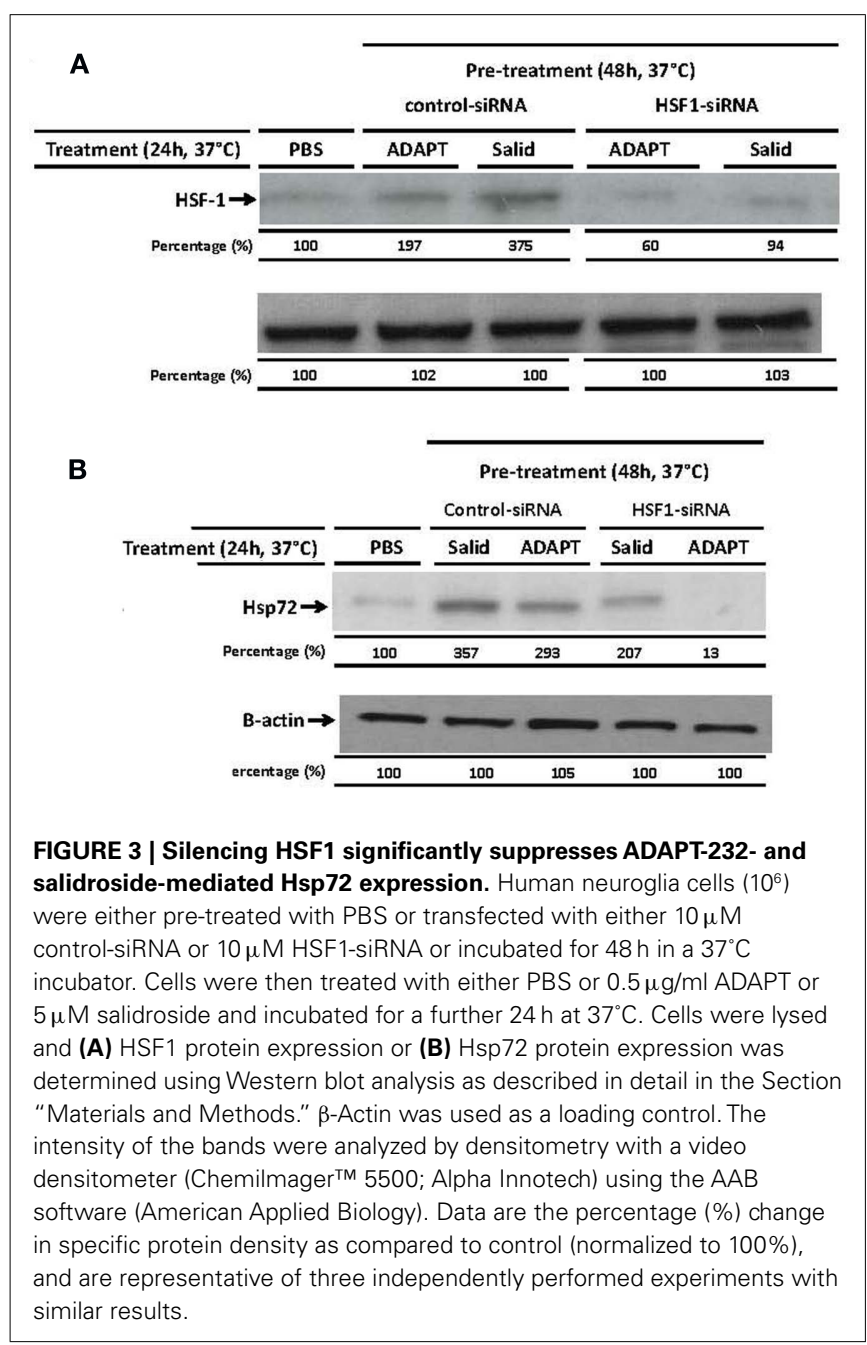

et al., 1991). Our study is in line both with reports on morphine anti-withdrawal effect of NPY (Woldbye et al., 1998) and recent studies in which the anti-narcotic effect of Rhodiola extract has been demonstrated (Mattioli et al., 2009). Our study is also in line with a recent finding that salidroside (but not rosavin) at doses present in the Rhodiola extract, dose-dependently reduced, or abolished binge eating (Cifani et al., 2010). The reason for this is thus far not known. However, we hypothesize that this might be associated with the stimulation of NPY, which plays an important role in regulation of energy homeostasis, the imbalance of which is associated with eating disorders anorexia and bulimia nervosa (Sedlackova et al., 2011). This is in agreement with a study demonstrating that NPY acts to stimulate behavior, which precedes the food intake and actually inhibits the food intake per se (Nergardh et al., 2007). In addition, the treatment with NPY increased physical activity and decreased food intake and caused a loss of body weight (Sederholm et al., 2002).

Based on the results of this study we hypothesize that NPY, being itself a kind of a "host adaptogen," plays a key role in modulation of adaptogenic activity of ADAPT-232 (and possibly other plant adaptogens), increasing resistance of the organism to stress.

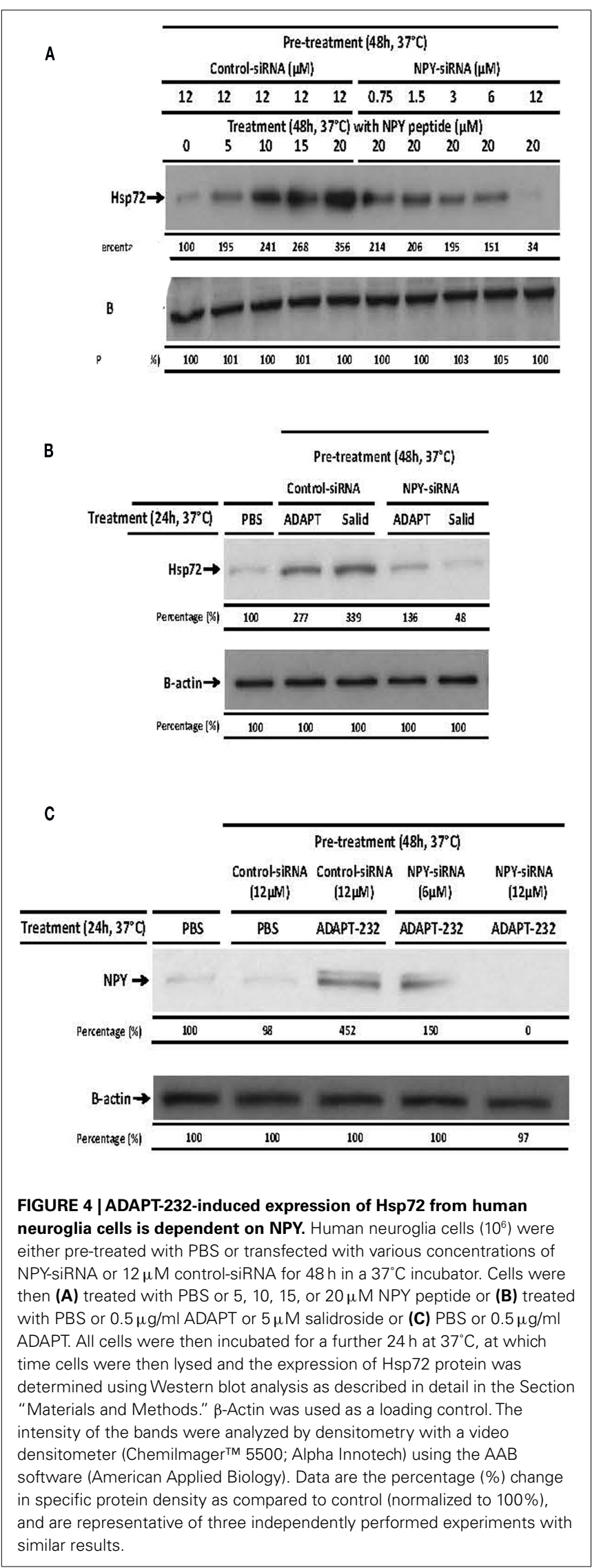



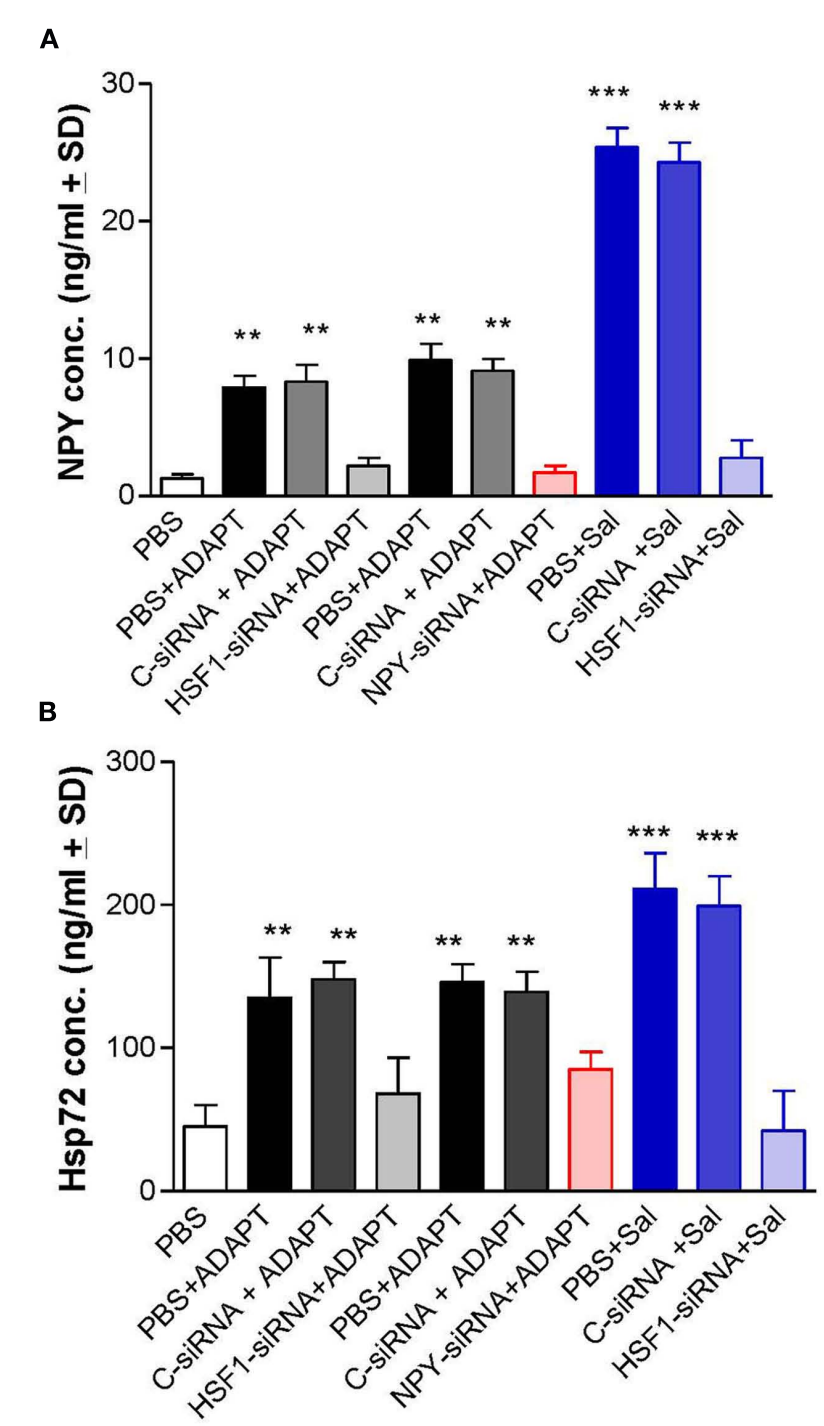

FIGURE 5 | ADAPT-232 and its active constituent salidroside induce the release of Hsp72 and NPY via a mechanism dependent on the

upregulation of HSF1. Human neuroglia cells $\left(10^{6}\right)$ were either pre-treated with PBS or transfected with either $10 \mu \mathrm{M}$ control-siRNA (control) or $10 \mu \mathrm{M}$ HSF1-siRNA or $12 \mu \mathrm{M}$ NPY-siRNA or exposed to heat shock $\left(41^{\circ} \mathrm{C}, 60 \mathrm{~min}\right)$ and incubated for $48 \mathrm{~h}$ in a $37^{\circ} \mathrm{C}$ incubator. Cells were then treated with either PBS or $0.5 \mu \mathrm{g} / \mathrm{ml}$ ADAPT-232 $(0.005 \mu \mathrm{M}$ salidroside) or $5 \mu \mathrm{M}$ salidroside and incubated for a further $24 \mathrm{~h}$ at $37^{\circ} \mathrm{C}$. Twenty-four hours after treatment protocols the supernatant from human neuroglia cells were recovered, centrifuged to clear cellular debris and (A) NPY or (B) Hsp72 concentrations were measured using the NPY enzyme immunoassay kit (assay sensitivity of $0.09 \mathrm{ng} / \mathrm{ml}$ ) according to the manufacturer's instructions (Phoenix Pharmaceuticals, CA, USA), or the classical Hsp72 ELISA as described in detail in the Section "Materials and Methods." Data are the mean concentration of NPY $(\mathrm{ng} / \mathrm{ml} \pm \mathrm{SD}), \mathrm{Hsp} 72(\mathrm{ng} / \mathrm{ml} \pm \mathrm{SD})$, and is the sum of three independent experiments performed in quadruplicates. ${ }^{*} p<0.05$ vs control (control-siRNA). Twenty-four hours after treatment protocols the supernatant from human neuroglia cells and viability were assayed using the CytoTox 96 Non-Radioactive Cytotoxicity Assay according to the manufacturer's instructions (Promega), and the percentage of LDH released vs total LDH was calculated. Data are mean percentage cell death $\pm S D$ and represent four independently performed experiments in quadruplicates. ${ }^{*} p<0.001$ vs control $(0 \mu \mathrm{g} / \mathrm{ml}$ genuine extracts $)$.

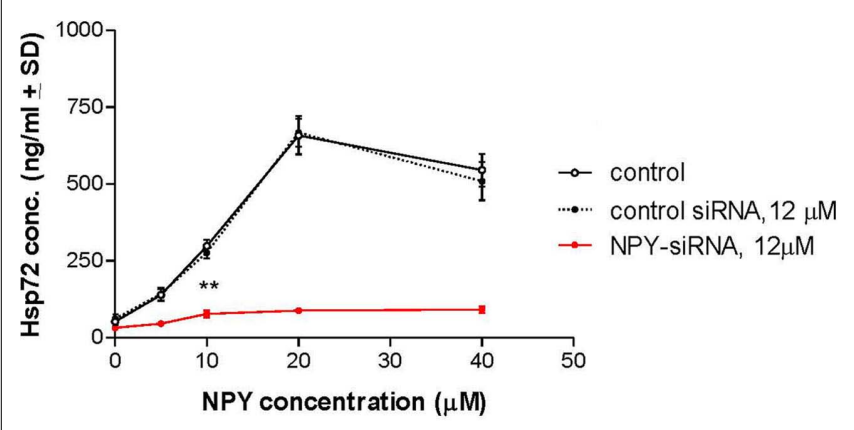

FIGURE 6 | Effect of NPY on Hsp72 release from human neuroglia cells. Treatment of human neuroglia cells with NPY peptide dose-dependently increased the release of Hsp72. Human neuroglia cells $\left(10^{6}\right)$ were transfected with either $12 \mu \mathrm{M}$ control-siRNA or $12 \mu \mathrm{M}$ NPY-siRNA for $48 \mathrm{~h}$ at $37^{\circ} \mathrm{C}$. Cells were then treated with either various concentrations of NPY peptide or $40 \mu \mathrm{M}$ PB1 (control peptide) and incubated for a further $24 \mathrm{~h}$ at $37^{\circ} \mathrm{C}$. Twenty-four hours after treatment protocols the supernatant from human neuroglia cells were recovered, centrifuged to clear cellular debris, and Hsp72 concentration was measured using the classical Hsp72 ELISA as described in detail in the Section "Materials and Methods." Data are the mean concentration of $\mathrm{Hsp} 72(\mathrm{ng} / \mathrm{ml} \pm \mathrm{SD}$ ) and is the sum of five independent experiments performed in quadruplicate. ${ }^{*} p<0.05$ vs control-siRNA. Twenty-four hours after treatment protocols the supernatant from human neuroglia cells and viability were assayed using the CytoTox 96 Non-Radioactive Cytotoxicity Assay according to the manufacturer's instructions (Promega), and the percentage of LDH released vs total LDH was calculated. Data are mean percentage cell death \pm SD and represent three independently performed experiments in quadruplicates. ${ }^{*} p<0.001$ vs PB1 (control peptide). ${ }^{\ddagger} p<0.001$ vs control-siRNA.

\section{Table 2 | Similarities in pharmacological profiles of adaptogens and} NPY.

Activity NPY Adaptogens

Stress response modifying (protective and mimetic) $+\quad+$ effect

Stimulation of HPA axis, modulation of cortisol release

Stimulation of CNS system

Effect on endocrine system (via cortisol, insulin, etc.)

Stimulation of immune system (via Hsp72)

Effect on sympathetic and parasympathetic system

Effect on energy homeostasis

Anabolic effect

Effect on physical endurance, locomotor activity

Effect on cognitive function (attention, memory)

Cardiovascular effects, vasoconstrictor

Anti-narcotic effect

Cytoprotection (via Hsp72)

Anti-aging (via Hsp72 and FoxO)

$+\quad+$

$+\quad+$

$+\quad+$

$+\quad+$

$+\quad+$

$+\quad+$

$+\quad+$

$+\quad+$

$+\quad+$

$+\quad+$

$+\quad+$

$+\quad+$

$+\quad+$

+ , See the references on relevant publications, reference list and the reviews on adaptogens (Brekhman and Dardymov, 1969; Panossian, 2003; Panossian and Wagner, 2005; Panossian and Wikman, 2008, 2009, 2010).

One of the active constituents of ADAPT is salidroside, which also stimulates expression of NPY at concentrations approximately 100-1,000 times higher than in ADAPT. It might be speculated that 
Table 3 | NPY-mediated beneficial effects ${ }^{\ddagger}$ and potential effects ${ }^{\S}$ of adaptogens in various disorders.

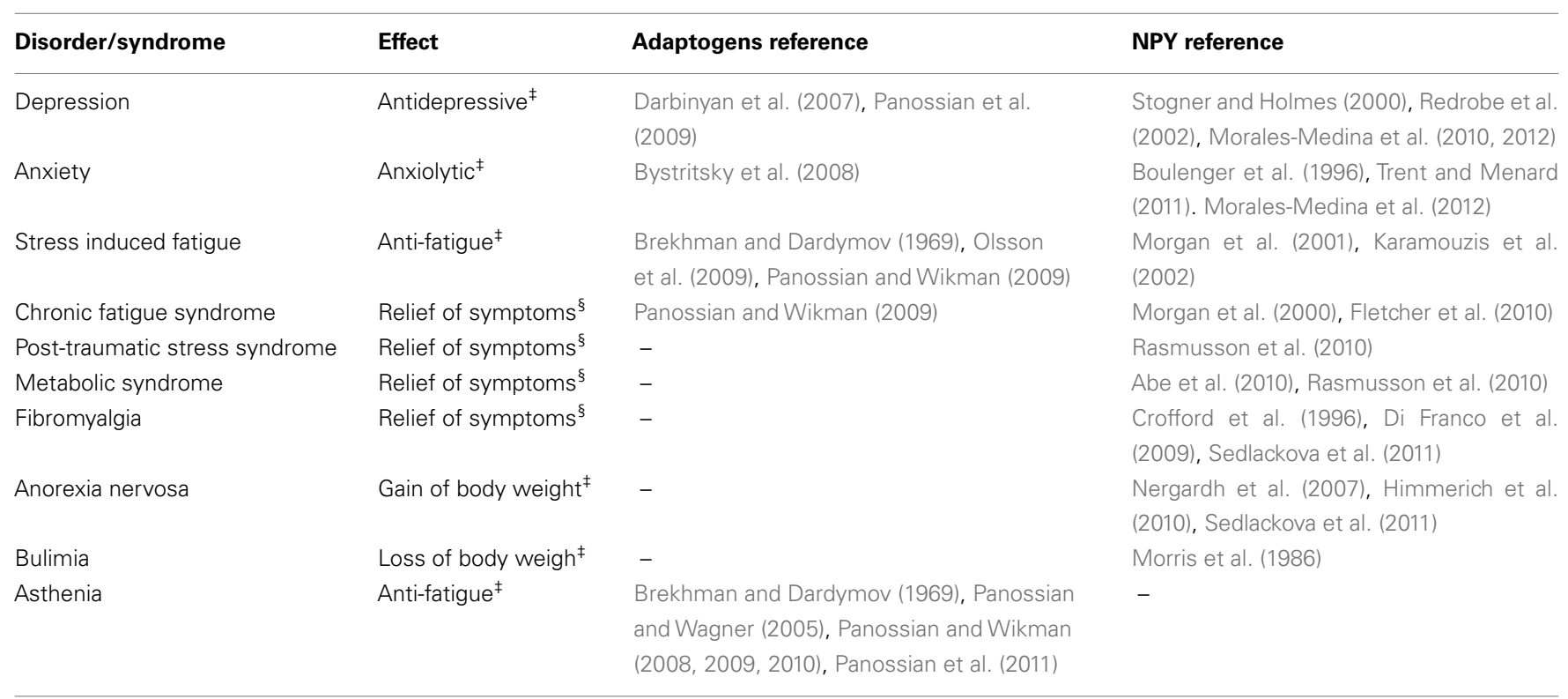

ADAPT contains some other active compound(s) synergistically increasing the expression of NPY. Interestingly tyrosol, salidroside, and NPY contain five tyrosine residues (Labelle et al., 1997), and all have the same $p$-hydroxyl-methylene residue. The importance the tyrosine moieties for brain receptors binding and NPY activity has been demonstrated (Martel et al., 1990). We hypothesize that the $p$-hydroxyl-methylene residue of the tyrosine unit (in polypeptide chain of NPY), and $p$-hydroxyl-ethylene residue of tyrosol and salidroside (in ADAPT-232) can compete on the receptor binding site. In support of this speculation, we demonstrated that ADAPT-232 and salidroside dose-dependently stimulate the expression (Figure 1) and release (Table 1) of Hsp72 in human neuroglia cells. Again, salidroside alone is active in concentrations significantly higher than it is in ADAPT-232 reviling a similar effect on release of Hsp72 from neuroglia cells (Figure 5). In the next series of experiments, we demonstrated that ADAPT-232 significantly activates HSF1, a protein known to initiate the synthesis of Hsp72 (Wu, 1995), However, ADAPT-232 is inactive in "silent" cells transfected by HSF1-siRNA which effectively inhibits baseline levels of HSF1 expression (Figure 3A).

Interferences RNA technology (RNAi) was also used to abrogate the expression of HSF1 (using HSF1-siRNA) in order to clarify what is upstream of NPY, HSF1, and Hsp72 activation. Figure 5 demonstrated that ADAPT-232 and an active constituent salidroside induce the release of Hsp72 via a mechanism dependent on the upregulation of HSF1. Pre-treatment of human neuroglia cells HSF1-siRNA, which silences/knock down the expression of intracellular HSF1, before treatment with ADAPT-232 or salidroside, resulted in a significant suppression of Hsp72 and NPY release (Figure 5). We further demonstrated that pre-treatment of human neuroglia cells with NPY-siRNA, which silences/knock down the expression of intracellular NPY, before treatment with ADAPT232 or salidroside resulted in a significant suppression of Hsp72 expression and release (Figures $\mathbf{3 A}, \mathbf{3 B}$ and $\mathbf{5}$ ).In a separate set of experiments, we demonstrated that the treatment of human neuroglia cells with NPY peptide dose-dependently increases the expression and release of Hsp72 (Figure 6). These results are in agreement with recent findings that NPY stimulates Hsp72 in rat renal vascular smooth muscle (Zhong et al., 2003).

In this study we demonstrated that ADAPT-232-induced expression and release of $\mathrm{Hsp} 72$ from glioma cells was dependent of HSF1 or NPY. The general mechanism of activation and regulation of Hsp72 by HSF1 in the brain and aging is well elucidated (Asea and Brown, 2008; Calderwood et al., 2009). However, the mechanism activation of Hsp72 by NPY still remains uncertain. The expression of NPY receptors on glial cells has been demonstrated (Canto Soler et al., 2002; Hashimoto et al., 2011). Recently, the $\mathrm{Y}(1)$ receptor has been demonstrated to play an essential role in mediating NPY-induced NO and IL- $1 \beta$ production in microglia (Ferreira et al., 2010). However, further studies are required to elucidate the exact mechanism of action and the signaling pathway utilized by NPY receptors to transducer it beneficial effects.

Taken together our studies suggest that the ADAPT-232 and its active constituent salidroside act on NPY expression via a mechanism dependent on the upregulation of HSF1 expression, which is upstream of Hsp72 expression, which is upstream of Hsp72 release (Figure 7). Our hypothetical model suggest that the release of Hsp72 take place via a mechanism dependent on the upregulation of NPY, which is upstream of Hsp72 and all other mediators of stress response involved in effects of ADAPT232 (Figure 7). ADAPT-232 stimulates secretion of NPY which is known to play an important role in regulation of HPA axis and energy homeostasis and secretion of Hsp72, playing an important role in cytoprotection and innate immunity. Hsp72 in turn inhibits FoxO transcription factor, playing an important role in adaptation to stress and longevity (Lam et al., 2006; Senf et al., 2010). These pathways contribute the anti-fatigue effect of ADAPT, increase attention and the improvement in cognitive function. 


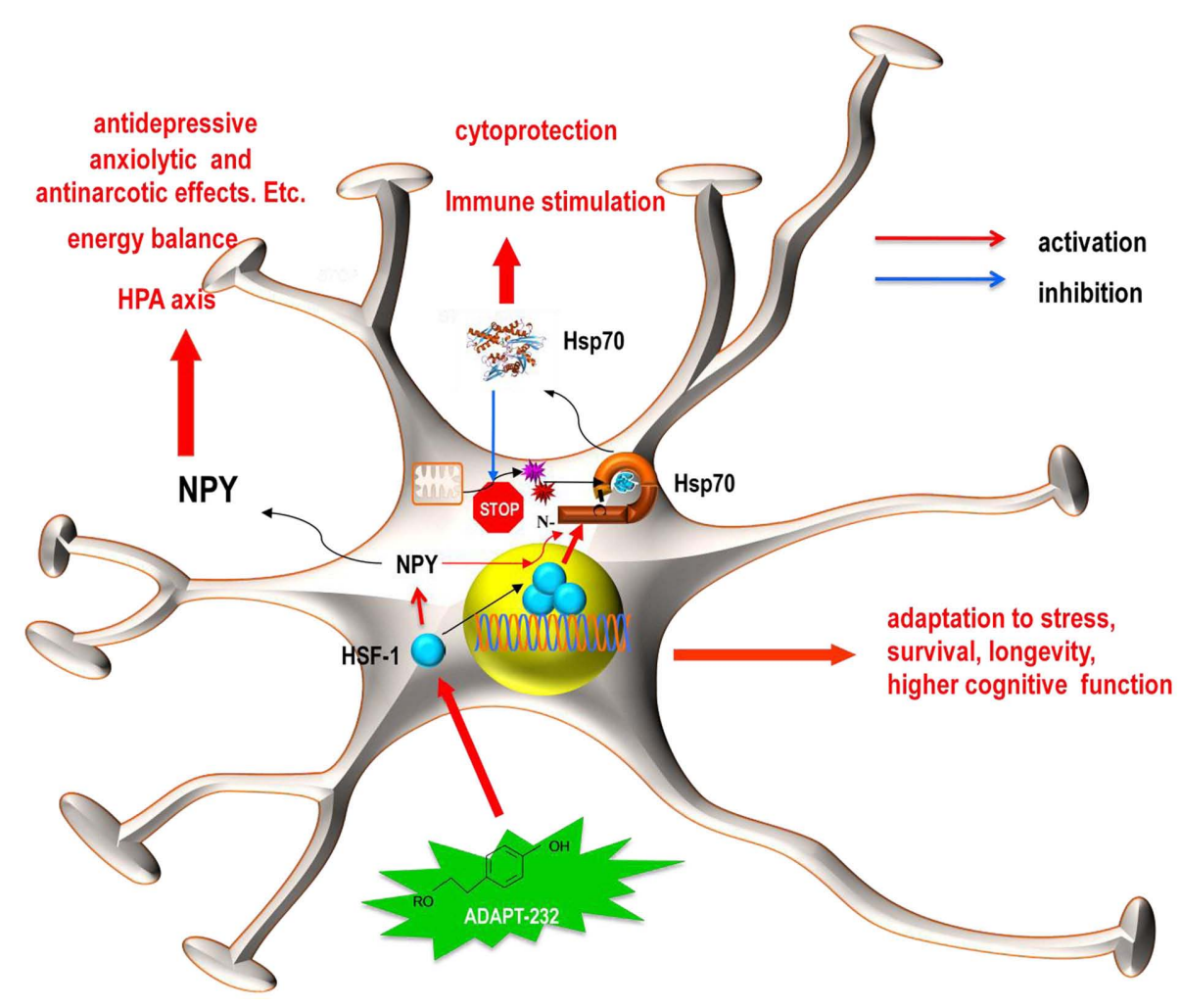

FIGURE 7 | Schematics representation of the hypothetical working model for the effect of ADAPT-232 on neuroglia cells. ADAPT-232 (green star) and its active constituent salidroside activated the synthesis and release of NPY and Hsp72 via a HSF1-dependent mechanism, including the trimerization and nuclear translocation of HSF1 (blue circles). Hsp72 functions intracellularly to enhance anti-apoptotic mechanisms, protect proteins against mitochondria generated oxygen-containing radicals, including nitric oxide (red star) and superoxide anion (purple star). The released Hsp72 acts as an endogenous danger signal and plays an important role in immune stimulation. While released NPY plays a crucial role in the HPA axis and maintains energy balance, both NPY and Hsp72 are directly involved in cellular adaptation to stress, increased survival, enhanced longevity, and an improvement in cognitive function.
The activation of NPY by ADAPT-232 initiates Hsp72 expression in human neuroglia cells, which are known to maintain homeostasis of neuronal cells. Stimulation and release of these stress hormones (NPY and Hsp72) into the blood circulating system apparently is an innate defense response to mild stressors (adaptogens), which increases tolerance and adaptation to stress. This gives rise to adaptive and stress-protective effects via various components of central nervous, sympathetic, endocrine, immune, cardiovascular, and gastrointestinal systems. Both NPY and Hsp72 play important roles in stress, regulation of aging, and pathogenesis of age-related diseases (Kmiec, 2006; Calderwood et al., 2009; Rasmusson et al., 2010). Taken together, the data presented in this study suggests that adaptogenic activity of ADAPT-232, such as increased mental performance, attention, endurance, tolerance to

\section{REFERENCES}

Abe, K., Kuo, L., and Zukowska, Z. (2010). Neuropeptide $Y$ is a mediator of chronic vascular and metabolic maladaptations to stress and hypernutrition. Exp. Biol. Med. (Maywood) 235, 1179-1184.

Antonijevic, I. A., Murck, H., Bohlhalter, S., Frieboes, R. M., Holsboer, F., and Steiger, A. (2000). Neuropeptide $Y$ promotes sleep and inhibits ACTH and cortisol release in young men. Neuropharmacology 39, 1474-1481.

Asea, A. (2006). Initiation of the immune response by extracellular Hsp72: chaperokine activity of Hsp72. Curr. Immunol. Rev. 2, 209-215.

stress, and beneficial effects on age-related disorders are associated with activation of NPY and Hsp72 gene expression in neuroglia cells and the release of NPY and Hsp72 into the systemic blood circulation.

\section{ACKNOWLEDGMENTS}

This work was supported in part by the Swedish Herbal Institute (Alexander Panossian, Georg Wikman); Scott \& White Memorial Hospital and Clinic Research Advancement Awards (Punit Kaur); the U.S. National Institute of Health (RO1CA91889), Scott \& White Memorial Hospital and Clinic, the Texas A\&M Health Science Center College of Medicine (Alexzander Asea), the Central Texas Veterans Health Administration and an Endowment from the Cain Foundation (Alexzander Asea).

Asea, A. (2007). "Release of heat shock proteins: passive vs active release mechanisms," in Potent Mediators of Inflammation and Immunity, eds A. Asea and S. K. Calderwood (Dordrecht: Springer), 3-20.

Asea, A. (2003). Chaperokineinduced signal transduction pathways. Exerc. Immunol. Rev. 9, 25-33.

Asea, A. (2008). Hsp70: a chaperokine. Novartis Found. Symp. 291, 173-179; discussion 179-183, 221-174.

Asea, A., and Brown, I. R. (2008). Heat Shock Proteins and the Brain: Implications for Neurodegenerative 
Diseases and Neuroprotection. Dordrecht: Springer Science.

Aslanyan, G., Amroyan, E., Gabrielyan, E., Nylander, M., Wikman, G., and Panossian, A. (2010). Double-blind, placebo-controlled, randomised study of single dose effects of ADAPT-232 on cognitive functions. Phytomedicine 17, 494-499.

Billington, C. J., Briggs, J. E., Harker, S., Grace, M., and Levine, A. S. (1994). Neuropeptide Y in hypothalamic paraventricular nucleus: a center coordinating energy metabolism. Am. J. Physiol. 266, R1765-R1770.

Bogatova, R., Shlyakova, L., Salnitsky, V., and Wikman, G. (1997). Evaluation of the effect of single take of a phytoadaptogen on human subject work ability during long isolation. Aerospace Environ. Med. 31, 51-54.

Boulenger, J. P., Jerabek, I., Jolicoeur, F. B., Lavallee, Y. J., Leduc, R., and Cadieux, A. (1996). Elevated plasma levels of neuropeptide $\mathrm{Y}$ in patients with panic disorder. Am. J. Psychiatry 153, 114-116.

Brekhman, I. I., and Dardymov, I. V. (1969). New substances of plant origin which increase nonspecific resistance. Annu. Rev. Pharmacol. 9, 419-430.

Bystritsky, A., Kerwin, L., and Feusner, J. D. (2008). A pilot study of Rhodiola rosea (Rhodax) for generalized anxiety disorder (GAD). J. Altern. Complement. Med. 14, 175-180.

Calderwood, S. K., Murshid, A., and Prince, T. (2009). The shock of aging: molecular chaperones and the heat shock response in longevity and aging - a mini-review. Gerontology 55, 550-558.

Canto Soler, M. V., Gallo, J. E., Dodds, R. A., Hokfelt, T., Villar, M. J., and Suburo, A. M. (2002). Y1 receptor of neuropeptide $\mathrm{Y}$ as a glial marker in proliferative vitreoretinopathy and diseased human retina. Glia 39, 320-324.

Chiu, P. Y., and Ko, K. M. (2004). Schisandrin B protects myocardial ischemia-reperfusion injury partly by inducing Hsp25 and Hsp70 expression in rats. Mol. Cell. Biochem. 266, 139-144.

Cifani, C., Micioni Di, B. M., Vitale, G., Ruggieri, V., Ciccocioppo, R., and Massi, M. (2010). Effect of salidroside, active principle of Rhodiola rosea extract, on binge eating. Physiol. Behav. 101, 555-562.

Crofford, L. J., Engleberg, N. C., and Demitrack, M. A. (1996). Neurohormonal perturbations in fibromyalgia. Baillieres Clin. Rheumatol. 10, 365-378.
Darbinyan, V., Aslanyan, G., Amroyan, E., Gabrielyan, E., Malmstrom, C. and Panossian, A. (2007). Clinical trial of Rhodiola rosea L. extract SHR-5 in the treatment of mild to moderate depression. Nord. J. Psychiatry 61, 343-348.

Di Franco, M., Iannuccelli, C., Alessandri, C., Paradiso, M., Riccieri, V., Libri, F., and Valesini, G. (2009). Autonomic dysfunction and neuropeptide $\mathrm{Y}$ in fibromyalgia. Clin. Exp. Rheumatol. 27, S75-S78.

Du, M., Butchi, N. B., Woods, T., Morgan, T. W., and Peterson, K. E. (2010). Neuropeptide Y has a protective role during murine retrovirus-induced neurological disease. J. Virol. 84, 11076-11088.

Dumont, Y., Fournier, A., St-Pierre, S., and Quirion, R. (1993). Comparative characterization and autoradiographic distribution of neuropeptide $\mathrm{Y}$ receptor subtypes in the rat brain. J. Neurosci. 13, 73-86.

Ferreira, R., Xapelli, S., Santos, T., Silva, A. P., Cristovao, A., Cortes, L., and Malva, J. O. (2010). Neuropeptide Y modulation of interleukin$1\{$ beta\} (IL-1 $\{$ beta $\}$ )-induced nitric oxide production in microglia. $J$. Biol. Chem. 285, 41921-41934.

Fletcher, M. A., Rosenthal, M., Antoni, M., Ironson, G., Zeng, X. R., Barnes, Z., Harvey, J. M., Hurwitz, B., Levis, S., Broderick, G., and Klimas, N. G. (2010). Plasma neuropeptide Y: a biomarker for symptom severity in chronic fatigue syndrome. Behav. Brain Funct. 6, 76.

Hashimoto, R., Udagawa, J., Kagohashi, Y., Matsumoto, A., Hatta, T., and Otani, H. (2011). Direct and indirect effects of neuropeptide $\mathrm{Y}$ and neurotrophin 3 on myelination in the neonatal brains. Brain Res. 1373, 55-66.

Hecker, J. G., and McGarvey, M. (2011). Heat shock proteins as biomarkers for the rapid detection of brain and spinal cord ischemia: a review and comparison to other methods of detection in thoracic aneurysm repair. Cell Stress Chaperones 16, 119-131.

Heilig, M., Wahlestedt, C., Ekman, R., and Widerlov, E. (1988). Antidepressant drugs increase the concentration of neuropeptide Y (NPY)like immunoreactivity in the rat brain. Eur. J. Pharmacol. 147, 465-467.

Himmerich, H., Schonknecht, P., Heitmann, S., and Sheldrick, A. J. (2010). Laboratory parameters and appetite regulators in patients with anorexia nervosa. J. Psychiatr. Pract. $16,82-92$.
Irwin, M. R. (2008). Human psychoneuroimmunology: 20 years of discovery. Brain Behav. Immun. 22, 129-139.

Karamouzis, I., Karamouzis, M., Vrabas, I. S., Christoulas, K., Kyriazis, N., Giannoulis, E., and Mandroukas, K. (2002). The effects of marathon swimming on serum leptin and plasma neuropeptide Y levels. Clin. Chem. Lab. Med. 40, 132-136.

Kellogg, D. L. Jr. (2006). In vivo mechanisms of cutaneous vasodilation and vasoconstriction in humans during thermoregulatory challenges. $J$. Appl. Physiol. 100, 1709-1718.

Kempna, P., Korner, M., Waser, B., Hofer, G., Nuoffer, J. M., Reubi, J. C., and Fluck, C. E. (2010). Neuropeptide $\mathrm{Y}$ modulates steroid production of human adrenal H295R cells through Y1 receptors. Mol. Cell. Endocrinol. 314, 101-109.

Kmiec, Z. (2006). Central regulation of food intake in ageing. J. Physiol. Pharmacol. 57(Suppl. 6), 7-16.

Kuo, L. E., Abe, K., and Zukowska, Z. (2007). Stress, NPY and vascular remodeling: Implications for stress-related diseases. Peptides 28, 435-440.

Labelle, M., St-Pierre, S., Savard, R., and Boulanger, Y. (1997). Solution structure of neuropeptide tyrosine 13-36, a Y2 receptor agonist, as determined by NMR. Eur. J. Biochem. 246, 780-785.

Lam, E. W., Francis, R. E., and Petkovic, M. (2006). FOXO transcription factors: key regulators of cell fate. Biochem. Soc. Trans. 34, 722-726.

Makarov, V. G., Makarova, M. N., Stolaschyck, N. V., Wikman, G., and Panossian, A. (2007). Potential Use of Plant Adaptogen in Age Related Disorders, Celebration of the Centennia Birth of Hans Selye. Budapest. Hungary: Cell Stress and Chaperones, 242.

Martel, J. C., Fournier, A., St-Pierre, S. Dumont, Y., Forest, M., and Quirion, R. (1990). Comparative structural requirements of brain neuropeptide $\mathrm{Y}$ binding sites and vas deferens neuropeptide Y receptors. Mol. Pharmacol. 38, 494-502.

Mattioli, L., Funari, C., and Perfumi, M. (2009). Effects of Rhodiola rosea L. extract on behavioural and physiological alterations induced by chronic mild stress in female rats. $J$. Psychopharmacol. 23, 130-142.

Morales-Medina, J. C., Dumont, Y., Benoit, C. E., Bastianetto, S., Flores, G., Fournier, A., and Quirion, R. (2012). Role of neuropeptide Y Y(1) and $\mathrm{Y}(2)$ receptors on behavioral despair in a rat model of depression with co-morbid anxiety. Neuropharmacology 62, 200-208.

Morales-Medina, J. C., Dumont, Y., and Quirion, R. (2010). A possible role of neuropeptide $\mathrm{Y}$ in depression and stress. Brain Res. 1314, 194-205.

Morgan, C. A. III, Wang, S., Rasmusson, A., Hazlett, G., Anderson, G., and Charney, D. S. (2001). Relationship among plasma cortisol, catecholamines, neuropeptide $\mathrm{Y}$, and human performance during exposure to uncontrollable stress. Psychosom. Med. 63, 412-422.

Morgan, C. A. III, Wang, S., Southwick, S. M., Rasmusson, A., Hazlett, G., Hauger, R. L., and Charney, D. S. (2000). Plasma neuropeptide-Y concentrations in humans exposed to military survival training. Biol. Psychiatry 47, 902-909.

Morris, M. J., Russell, A. E., Kapoor, V., Cain, M. D., Elliott, J. M., West, M. J., Wing, L. M., and Chalmers, J. P. (1986). Increases in plasma neuropeptide $\mathrm{Y}$ concentrations during sympathetic activation in man. J. Auton. Nerv. Syst. 17, 143-149.

Narimanian, M., Badalyan, M. Panosyan, V., Gabrielyan, E., Panossian, A., Wikman, G., and Wagner, H. (2005). Impact of Chisan (ADAPT-232) on the quality-of-life and its efficacy as an adjuvant in the treatment of acute non-specific pneumonia. Phytomedicine 12, 723-729.

Nergardh, R., Ammar, A., Brodin, U., Bergstrom, J., Scheurink, A., and Sodersten, P. (2007). Neuropeptide Y facilitates activity-basedanorexia. Psychoneuroendocrinology 32, 493-502.

Olsson, E. M., von Scheele, B., and Panossian, A. G. (2009). A randomised, double-blind, placebocontrolled, parallel-group study of the standardised extract shr-5 of the roots of Rhodiola rosea in the treatment of subjects with stress-related fatigue. Planta Med. 75, 105-112.

Pages, N., Orosco, M., Fournier, G., Rouch, C., Hafi, A., Gourch, A., Comoy, E., and Bohuon, C. (1991). The effects of chronic administration of morphine on the levels of brain and adrenal catecholamines and neuropeptide $\mathrm{Y}$ in rats. Gen. Pharmacol. 22, 943-947.

Panossian, A. (2003). Adaptogens: tonic herbs for fatigue and stress. Altern. Compement. Therap. 9, 327-332.

Panossian, A., Hambartsumyan, M. Hovanissian, A., Gabrielyan, E., and Wilkman, G. (2007). The adaptogens Rhodiola and Schizandra modify the response to immobilization stress in rabbits by suppressing the 
increase of phosphorylated stressactivated protein kinase, nitric oxide and cortisol. Drug Targets Instights 1, 39-54.

Panossian, A., and Wagner, H. (2005). Stimulating effect of adaptogens: an overview with particular reference to their efficacy following single dose administration. Phytother. Res. 19, 819-838.

Panossian, A., and Wikman, G. (2008). Pharmacology of Schisandra chinensis Bail.: an overview of Russian research and uses in medicine. $J$. Ethnopharmacol. 118, 183-212.

Panossian, A., and Wikman, G. (2009). Evidence-based efficacy of adaptogens in fatigue, and molecular mechanisms related to their stressprotective activity. Curr. Clin. Pharmacol. 4, 198-219.

Panossian, A., and Wikman, G. (2010). Effects of adaptogens on the central nervous system and the molecular mechanisms associated with their stress-protective activity. Pharmaceuticals 3, 188-224.

Panossian, A., Wikman, G., Kaur, P., and Asea, A. (2009). Adaptogens exert a stress-protective effect by modulation of expression of molecular chaperones. Phytomedicine 16, 617-622.

Panossian, A., Wikman, G., Kaur, P., and Asea, A. (2010). "Molecular chaperones as mediators of stress protective effect of plant adaptogens," in Heat Shock Proteins and Whole Body Physiology, eds A. Asea and B. K. Pedersen (Dordrecht: Springer), 351-364.

Panossian, A., Wikman, G., and Sarris, J. (2011). Rosenroot (Rhodiola rosea): traditional use, chemical composition, pharmacology and clinical efficacy. Phytomedicine 17, 481-493.

Panossian, A., Wikman, G., and Wagner, H. (1999). Plant adaptogens. III. Earlier and more recent aspects and concepts on their mode of action. Phytomedicine 6, 287-300.
Rasmusson, A. M., Schnurr, P. P., Zukowska, Z., Scioli, E., and Forman, D. E. (2010). Adaptation to extreme stress: post-traumatic stress disorder, neuropeptide $\mathrm{Y}$ and metabolic syndrome. Exp. Biol. Med. (Maywood) 235, 1150-1162.

Redrobe, J. P., Dumont, Y., Fournier, A., and Quirion, R. (2002). The neuropeptide Y (NPY) Y1 receptor subtype mediates NPY-induced antidepressant-like activity in the mouse forced swimming test. Neuropsychopharmacology 26, 615-624.

Redrobe, J. P., Dumont, Y., St-Pierre, J. A., and Quirion, R. (1999). Multiple receptors for neuropeptide $\mathrm{Y}$ in the hippocampus: putative roles in seizures and cognition. Brain Res. 848, 153-166.

Samuelsson, G., and Bohlin, L. (2009). Drugs of Natural Origin: A Treatise of Pharmacognosy, 6th Edn. Stockholm : Swedish Academy of Phramaceutical Sciences.

Sederholm, F., Ammar, A. A., and Sodersten, P. (2002). Intake inhibition by NPY: role of appetitive ingestive behavior and aversion. Physiol. Behav. 75, 567-575.

Sedlackova, D., Kopeckova, J., Papezova, H., Vybiral, S., Kvasnickova, H., Hill, M., and Nedvidkova, J. (2011). Changes of plasma obestatin, ghrelin and NPY in anorexia and bulimia nervosa patients before and after a high-carbohydrate breakfast. Physiol. Res. 60, 165-173.

Senf, S. M., Dodd, S. L., and Judge, A. R. (2010). FOXO signaling is required for disuse muscle atrophy and is directly regulated by Hsp70. Am. J. Physiol. Cell Physiol. 298, C38-C45.

Small, C. J., Morgan, D. G., Meeran, K., Heath, M. M., Gunn, I., Edwards, C. M., Gardiner, J., Taylor, G. M., Hurley, J. D., Rossi, M., Goldstone, A. P., O'Shea, D., Smith, D. M., Ghatei, M. A., and Bloom, S. R. (1997). Peptide analogue studies of the hypothalamic neuropeptide Y receptor mediating pituitary adrenocorticotrophic hormone release. Proc. Natl. Acad. Sci. U.S.A. 94, 11686-11691.

Smialowska, M., Wieronska, J. M. Domin, H., and Zieba, B. (2007). The effect of intrahippocampal injection of group II and III metobotropic glutamate receptor agonists on anxiety; the role of neuropeptide Y. Neuropsychopharmacology 32, 1242-1250.

Stogner, K. A., and Holmes, P. V. (2000). Neuropeptide-Y exerts antidepressant-like effects in the forced swim test in rats. Eur. J. Pharmacol. 387, R9-R10.

Stratakis, C. A., and Chrousos, G. P. (1995). Neuroendocrinology and pathophysiology of the stress system. Ann. N. Y. Acad. Sci. 771, 1-18.

Tatemoto, K., Carlquist, M., and Mutt, V. (1982). Neuropeptide Y - a novel brain peptide with structural similarities to peptide YY and pancreatic polypeptide. Nature 296, 659-660.

Trent, N. L., and Menard, J. L. (2011). Infusions of neuropeptide $\mathrm{Y}$ into the lateral septum reduce anxietyrelated behaviors in the rat. Pharmacol. Biochem. Behav. 99, 580-590.

Ubink, R., Calza, L., and Hokfelt, T. (2003). 'Neuro'-peptides in glia: focus on NPY and galanin. Trends Neurosci. 26, 604-609.

Wahlestedt, C., and Reis, D. J. (1993). Neuropeptide Y-related peptides and their receptors - are the receptors potential therapeutic drug targets? Annu. Rev. Pharmacol. Toxicol. 33, 309-352.

Wiegant, F. A., Surinova, S., Ytsma, E. Langelaar-Makkinje, M., Wikman, G., and Post, J. A. (2009). Plant adaptogens increase lifespan and stress resistance in C. elegans. Biogerontology 10, 27-42.

Woldbye, D. P., Klemp, K., and Madsen, T. M. (1998). Neuropeptide $\mathrm{Y}$ attenuates naloxone-precipitated morphine withdrawal via Y5-like receptors. J. Pharmacol. Exp. Ther. 284, 633-636.

Wu, C. (1995). Heat shock transcription factors: structure and regulation. Annu. Rev. Cell Dev. Biol. 11, 441-469.

Yang, L., Scott, K. A., Hyun, J., Tamashiro, K. L., Tray, N., Moran, T. H., and Bi, S. (2009). Role of dorsomedial hypothalamic neuropeptide $\mathrm{Y}$ in modulating food intake and energy balance. J. Neurosci. 29, 179-190.

Zhong, W. D., Zeng, G. Q., Hu, J. B., Cai, Y. B., Liu, J. K., Huang, S. H., Chen, M. S., and Wei, H. A. (2003). Stimulation of neuropeptide $\mathrm{Y}$ on heat shock protein expression in renal vascular smooth muscle and the inhibition thereon by losartan. Zhonghua Sheng Wu Yi Xue Gong Cheng Za Zhi 83, 515-517.

Conflict of Interest Statement: Punit Kaur, Alexzander Asea, and Alexander Panossian declare no competing financial interests. Georg Wikman is a stockholder in the Swedish Herbal Institute (SHI).

Received: 21 October 2011; paper pending published: 12 November 2011; accepted: 13 January 2012; published online: 01 February 2012

Citation: Panossian A, Wikman G, Kaur $P$ and Asea A (2012) Adaptogens stimulate neuropeptide $Y$ and Hsp72 expression and release in neuroglia cells. Front. Neurosci. 6:6. doi: 10.3389/fnins.2012.00006 This article was submitted to Frontiers in Neuroendocrine Science, a specialty of Frontiers in Neuroscience.

Copyright (C) 2012 Panossian, Wikman, Kaur and Asea. This is an open-access article distributed under the terms of the Creative Commons Attribution Non Commercial License, which permits noncommercial use, distribution, and reproduction in other forums, provided the original authors and source are credited. 